\title{
WIDOWDAŃSKIE PROWIZORIUM. GENEZA I ROZWÓJ PARLAMENTARYZMU W KRÓLESTWIE SERBÓW, CHORWATÓW I SLOWEŃCÓW
}

\author{
THE VIDOVDAN MAKESHIFT. THE ORIGIN AND DEVELOPMENT \\ OF PARLIAMENTARISM IN THE KINGDOM OF SERBS, \\ CROATS AND SLOVENES
}

Kingdom of Serbs, Croats and Slovenes formed after World War I was a model example of difficulties arising in the process of building the multinational and multiethnic states in the Balkans. The State mired in disputes between supporters of unitarization and federalism was a subject of gradual Serbization, which was expressed by imposition of Serbian systemic pattern and domination of Serbs in central authorities. In the mid 1920s political particularisms led to the collapse of parliamentary system and political destabilization, implied by the acts of ethnic and national violence. The decision of king Alexander Karađorđević to suspend the constitutional order and establish a dictatorship was an attempt to inhibit the process of State disintegration and expressed a tendency to marginalize the national representation and to restore the sovereign's dominant role in the political system, which was a characteristic feature of the evolution of the Balkan states.

Słowa kluczowe: historia Bałkanów, konstytucja widowdańska, Królestwo SHS, parlamentaryzm, Skupsztina

Key words: Balkan history, Vidovdan constitution, Kingdom of Serbs, Croats and Slovenes, parliamentarism, Skupshtina

* Dr hab. Tadeusz Czekalski, Uniwersytet Jagielloński, Instytut Historii, tadeusz.czekalski@uj.edu.pl,https://orcid.org/0000-0002-8494-1769

Tea rządów parlamentarnych, odwołujących się do konstytucji dotarła do krajów Półwyspu Bałkańskiego w II połowie XIX w., w ramach prób odgórnej aplikacji zachodnioeuropejskich wzorców ustrojowych. Społeczeństwa ukształtowane w realiach kilkusetletniej dominacji osmańskiej, a także lokalnych odmian prawa zwyczajowego były dalekie od takiego poziomu dojrzałości politycznej, który by umożliwiał tworzenie sprawnie funkcjonujących ponadlokalnych kolegialnych struktur władzy, a ich horyzonty polityczne zazwyczaj nie przekraczały granicy wsi czy też gminy i były zdominowane przez schematy patriarchalizmu i myślenia kolektywnego. O ile lokalne organy władzy mogły skupiać przedstawicieli wszystkich rodzin, o tyle tworzenie państwowych struktur władzy wymagało odwołania się do nieznanej mieszkańcom Bałkanów zasady reprezentacji politycznej.

Powstające na Bałkanach w XIX w. państwa narodowe w początkowej fazie swojego istnienia przyjmowały ustrój monarchiczny, z ograniczoną do minimum rolą wybieranych organów kolegialnych. Pierwszym spośród państw bałkańskich, w którym podjęto próbę aplikacji modelu demokracji parlamentarnej była Grecja. Ustawa o ustroju państwa z października 1864 r. definiowała państwo greckie jako „demokrację z królem 
na czele"1. Król zachował prawo zwoływania i rozwiązywania organu legislacyjnego, ale prawo stanowienia ustaw przyznano Izbie Deputowanych, wybieranej na cztery lata w wyborach tajnych, powszechnych i bezpośrednich. Po uchwaleniu konstytucji tyrnowskiej w 1879 r., a zwłaszcza po abdykacji Aleksandra Battenberga w 1886 r., także Bułgaria wkroczyła w epokę rządów parlamentarnych, kiedy centrum władzy przeniosło się z dworu królewskiego do siedziby rządu i stanowiącego jego zaplecze polityczne Zgromadzenia Narodowego. Serbska ustawa konstytucyjna z 1888 r. wprowadzała pojęcie „monarchii parlamentarnej”, ale pozycję ustrojową parlamentu ograniczały szerokie prerogatywy władcy, w tym możliwość rozwiązywania parlamentu i pozbawienia mocy prawnej wszystkich podjętych przez niego decyzji². O ile w przypadku Grecji i Bułgarii można mówić na przełomie XIX i XX w. o widocznym wzmocnieniu organów legislacyjnych, aspirujących do samodzielnego sprawowania władzy, o tyle w przypadku Serbii i Czarnogóry bardziej zasadne wydaje się określenie „,pseudoparlamentaryzmu”, użyte przez Ferdo Čulinovicia, odnoszące się do systemu, w którym parlament jest pozbawiony autonomii i w pełni podporządkowany monarsze, sprawującemu władzę nadrzędną ${ }^{3}$.

Rumen Daskałow dostrzega w specyfice bałkańskich partii politycznych jedną z największych trudności w budowie nowoczesnej demokracji liberalnej. Powstające na Bałkanach ugrupowania polityczne budowane poprzez zależności rodzinne i personalne koncentrowały się na działaniach lokalnych i partykularnych, przejawiając zarazem skłonności do uzależniania się od państw obcych ${ }^{4}$. Trudności w budowaniu tożsamości ponadlokalnej na Bałkanach pogłębiły doświadczenia I wojny światowej. Społeczeństwo greckie podzieliło się na zwolenników Elefteriosa Wenizelosa, sprzymierzeńca ententy i na proniemieckich monarchistów. W Bułgarii przeciwko proniemieckiej polityce dworu królewskiego wystąpili politycy partii chłopskiej, na czele z Aleksandrem Stambolijskim. Współpracujący z Serbią i Francją albański polityk Esad Pasza Toptani musiał zmierzyć się z wiernym polityce Stambułu i państw centralnych środowiskiem ortodoksyjnych muzułmanów. Po klęsce Serbii i Czarnogóry w 1916 r. północna część Albanii znalazła się pod okupacją austro-węgierską, a południowa pozostała w strefie wpływów greckich, włoskich i francuskich. Wywołane przez wojnę podziały polityczne w szczególny sposób naznaczyły narody południowosłowiańskie, które w przyszłości miały stworzyć wspólne państwo. Danina krwi złożona przez żołnierzy walczących po stronie ententy zapewniała Serbii i Czarnogórze pozycję uprzywilejowaną $\mathrm{w}$ stosunku do innych narodowości słowiańskich, które do 1918 r. zamieszkiwały teren Austro-Węgier i z konieczności lub z wyboru wspierały w czasie wojny wrogą koalicję państw centralnych.

${ }^{1}$ J. Bonarek, T. Czekalski, S. Sprawski, S. Turlej, Historia Grecji, Kraków 2005, s. 497.

2 O. Popović-Obradović, The Parliamentary System in Serbia 1903-1914, Belgrad 2013, s. 118. W Królestwie Czarnogóry parlament pojawił się po raz pierwszy w konstytucji z 1905 r., a rok później odbyły się pierwsze wybory.

${ }^{3}$ F. Čulinović, Državnopravni razvitak Jugoslavije, Zagreb 1963, s. 92.

${ }^{4}$ R. Daskalov, Development in the Balkan Periphery Prior to World War II. Some Reflections, „Südost-Forschungen” 1998, nr 57, s. 229-231. 
Deklaracja rządu serbskiego wydana w Niszu, w początkowej fazie wielkiej wojny (7 grudnia 1914 r.), za jeden z jej celów określała „wyzwolenie i zjednoczenie wszystkich, dotąd niewyzwolonych braci Serbów, Chorwatów i Słoweńców"s. Kluczową rolę w procesie tworzenia państwa jugosłowiańskiego odegrała deklaracja z Korfu, podpisana 20 lipca 1917 r. przez premiera Królestwa Serbii Nikolę Pašicia oraz przewodniczącego Komitetu Jugosłowiańskiego Ante Trumbicia. Zapowiedziano w nim powstanie wspólnego państwa Serbów, Chorwatów i Słoweńców, a zarazem określono ustrój przyszłego państwa jako demokratyczną monarchię parlamentarną, rządzoną przez dynastię Karađorđeviciów. Deklaracja nadawała pozycję uprzywilejowaną dynastii serbskiej, ale w kwestiach ustrojowych poprzestawała na ogólnikowych stwierdzeniach, zakładając ich uszczegółowienie w przyszłej konstytucji ${ }^{6}$.

Na początku października 1918 r. powstała w Zagrzebiu Rada Narodowa Słoweńców, Chorwatów i Serbów, stanowiąca zalążek przyszłego zjednoczonego państwa. Na czele Rady stanął Słoweniec Anton Korošec, a jego zastępcami zostali Chorwat Ante Pavelić i Serb Svetozar Pribičević. W dniu 29 października posłowie chorwackiego Saboru ogłosili zerwanie wszelkich związków formalnoprawnych z Austro-Węgrami i stworzenie samodzielnego państwa Królestwa Słoweńców, Chorwatów i Serbów [dalej: SHS], uznając Radę Narodową SHS w Zagrzebiu jako najwyższą władzę suwerenną w tym państwie. Realizując politykę zjednoczeniową, Rada wystosowała zaproszenie do regenta serbskiego Aleksandra o przyjęcie korony i proklamowanie zjednoczonego państwa ${ }^{7}$. Planom powstania nowego państwa zagrażały aspiracje włoskie do ziem południowosłowiańskich, odwołujące się do postanowień traktatu londyńskiego (16 kwietnia 1915 r.). W obliczu zagrożenia włoską ekspansją Rada Narodowa SHS w Zagrzebiu była skłonna jak najszybciej połączyć się z Serbią, nawet na niekorzystnych warunkach narzuconych przez Belgrad. Pozycję przetargową Serbii wzmocniły decyzje zgromadzeń narodowych Czarnogóry i Wojwodiny, które zdecydowały się przyłączyć bezpośrednio do państwa rządzonego przez dynastię Karađorđeviciów ${ }^{8}$.

Przygotowania do utworzenia nowego jugosłowiańskiego państwa trwały krótko i do tego w warunkach toczącej się wojny. Zagrożenie zewnętrzne sprzyjało kształtowaniu się unitarystycznej koncepcji jednoczenia narodów południowosłowiańskich, której promotorem były przede wszystkim kręgi polityczne dawnego Królestwa Serbii, dążące do podporządkowania słabszych narodów słowiańskich. Dominacji serbskiej w nowym państwie sprzyjało wsparcie państw należących do zwycięskiego w I wojnie światowej obozu ententy, traktujących Serbię jako swojego sprzymierzeńca. Postawa państw zwycięskich wzmacniała przekonanie polityków serbskich, że źródeł powstania

${ }^{5}$ J. Lampe, Balkans into Southeastern Europe, 1914-2014. A Century of War and Transition, Hampshire 2014, s. 40.

${ }^{6}$ W. Szulc, Przemiany gospodarcze i społeczne w Jugostawii w okresie międzywojennym 1918-1941, Poznań 1980, s. 21.

7 R.W. Seton-Watson, Jugoslavia and Croatia, ,Journal of the Royal Institute of International Affairs” 1929 , t. 8 , nr 2, s. 118.

${ }^{8}$ W. Szulc, op. cit., s. 24. 
nowego państwa nie należy szukać w dążeniach zjednoczeniowych narodów południowosłowiańskich, ale w udziale Serbii w koalicji, która zwyciężyła w wojnie. Głównym przeciwnikiem tej koncepcji stawali się politycy chorwaccy, którzy nie rezygnowali z zamiaru odegrania wiodącej roli w procesie zjednoczeniowym. Słabość chorwackiej alternatywy wynikała $\mathrm{z}$ braku poparcia dla niej ze strony innych narodów południowosłowiańskich.

\section{PARLAMENT TYMCZASOWY}

Utworzenie Królestwa SHS oznaczało zakończenie działalności wszystkich przedstawicielstw prawodawczych na terenie zjednoczonego państwa. Serbski parlament narodowy zebrał się po raz ostatni 14 grudnia 1918 r., a prace zakończył siedem dni później, przenosząc oficjalnie swoje funkcje na tymczasowe przedstawicielstwo narodowe Królestwa SHS. W przyjętej przez parlament proklamacji rządu serbskiego znalazło się stwierdzenie, że wszystkie czynniki polityczne działające na terytorium nowego państwa zgodnie przyjęły decyzję o utworzeniu jednego przedstawicielstwa dla całego Królestwa. Głównym jego zadaniem miało być uchwalenie ustawy umożliwiającej przeprowadzenie wyborów do konstytuanty. Członkowie tego parlamentu nie byli wybierani, ale mieli reprezentować wszystkie partie, które walczyły o zjednoczenie i wyzwolenie nowego państwa. W parlamencie tymczasowym każda $\mathrm{z}$ tych partii miała prawo samodzielnego wyznaczenia własnych posłów. Zgodnie z przyjętym kluczem terytorialnym dla Serbii z Macedonią i Kosowem zagwarantowano w parlamencie 84 miejsca, Chorwacji i Slawonii - 62, Bośni i Hercegowinie - 42, Słowenii - 32, Wojwodinie - 24, Dalmacji i Czarnogórze po 12, zaś Istrii — 49.

Parlament tymczasowy rozpoczął działalność 1 marca 1919 r. i funkcjonował do października 1920 r. Początkowe plany, aby zakończył swoją misję po sześciu miesiącach, z czasem zweryfikowano, a jego działalność przedłużyła się do blisko dwóch lat ${ }^{10}$. Pierwszym przewodniczącym Izby wybrano historyka i profesora Uniwersytetu Belgradzkiego Dragoljuba Dražę Pavlovicia ${ }^{11}$. Regulamin pracy parlamentu, a także formułę przysięgi, którą składali posłowie opracował rząd Stojana Proticia. Prawo inicjatywy ustawodawczej przyznano grupie co najmniej 20 posłów, a decyzje w parlamencie miały być podejmowane absolutną większością głosów posłów obecnych na sali12.

Poszczególne ugrupowania polityczne wchodzące w skład parlamentu dzieliły spory na temat formy państwa i jego organizacji wewnętrznej. Postawę obstrukcyjną wobec parlamentu tymczasowego reprezentowała część polityków chorwackich, którzy dążyli do utworzenia państwa federacyjnego. Wśród partii chorwackich prym wiodła Chorwacka

${ }^{9}$ S. Ramet, The Three Yugoslavias. State-building and Legitimation, 1918-2005, Washington 2006, s. 46.

${ }^{10}$ Po raz ostatni parlament tymczasowy zebrał się 28 września 1920 r.; А. Фира, Видовдански устав, Београд 2011, s. 25.

${ }^{11}$ D. Draża Pavlović zmarł kilka miesięcy po wyborze, a jego miejsce zajął S. Vukčević; А. Фира, op. cit., s. 25-26.

${ }_{12}$ А. Фира, op. cit., s. 54-55. 
Partia Chłopska, kierowana przez Stjepana Radicia. Przyznano jej cztery mandaty, ale posłowie chorwaccy odmówili wejścia do tymczasowego parlamentu, rozpoczynając tworzenie własnych struktur władzy. Na początku lutego 1919 r. S. Radić zwołał delegatów swojej partii ze wszystkich okręgów Chorwacji i Slawonii i na tym zgromadzeniu wysunął żądania utworzenia osobnej chorwackiej republiki chłopskiej ze stolicą w Zagrzebiu ${ }^{13}$. Radić domagał się, aby kluczowe dla państwa decyzje parlamentu konstytucyjnego podejmowano większością $2 / 3$ głosów i protestował przeciwko wnioskowi rządu, żeby posłowie składali przysięgę królowi. Określany przez Franjo Suklje mianem „nieodpowiedzialnego demagoga” Radić był orędownikiem rozwiązań republikańskich i przyznania Chorwatom wiodącej roli w nowym państwie ${ }^{14}$.

Wiodąca rola w parlamencie tymczasowym przypadła dwóm partiom serbskim: radykalnej i demokratycznej. Pierwsza z nich działała od lat osiemdziesiątych XIX w. i reprezentowała środowisko doświadczonych polityków dawnego Królestwa Serbii. Popierając wizję trójimiennego narodu (troimeni narod), złożonego z Serbów, Chorwatów i Słoweńców, to Serbom radykałowie przypisywali wiodącą rolę w procesie zjednoczenia, traktując serbskie tradycje polityczne jako dominantę jugosłowiańskiej tożsamości narodowej. Przywódca partii Nikola Pašić w 1921 r. tak określał charakter zjednoczonego państwa: „Kiedy powstawała konstytucja [widowdańska — uwaga T.C.], niektórzy z nas domagali się pewnej autonomii dla Chorwatów. Serbia poniosła takie ofiary na rzecz zjednoczenia i wyzwolenia, że nie można się było z tym zgodzić. Nie chcieliśmy, aby oni stali się sługami, a my panami, ale musimy mieć jasność, że to my Serbowie byliśmy jedynymi, którzy walczyli o wolność i sprawili, że zjednoczenie stało się możliwe"15.

Partia Demokratyczna była ugrupowaniem, które na scenie politycznej pojawiło się w 1919 r. i skupiło polityków serbskich, wywodzących się z ziem, które przed I wojną światową należały do Austro-Węgier. W programie partii z 1920 r. definiowała się ona jako ugrupowanie wszechjugosłowiańskie, deklarując dążenie do utworzenia jednolitego i niepodzielnego narodu jugosłowiańskiego ${ }^{16}$. Zgodnie z tym wszelkie podziały plemienne w społeczeństwie miały w krótkim czasie zniknąć w miarę umacniania się jugosłowiańskiej tożsamości narodowej ${ }^{17}$. W przeciwieństwie do Partii Radykalnej, demokraci utworzyli ugrupowanie heterogeniczne, złożone z grup polityków o zróżnicowanym poziomie doświadczenia politycznego i poglądów na kształt państwa. Taka

${ }_{13}$ F. Šulje, Centralism and Autonomy in Jugoslavia, „The Slavonic Review” 1923, t. 2, nr 5, s. 331.

${ }^{14}$ V. Maček, Memoari, Zagrzeb 2003, s. 52. W 1920 r. władze partii zdecydowały się na udział w pierwszych wyborach do Skupsztiny Królestwa SHS. W tym samym roku partia przyjęła nazwę Chorwackiej Republikańskiej Partii Chłopskiej, eksponując postulat zniesienia monarchii. Po wyborach 1920 r., w których partia uzyskała 50 mandatów, Radić na zjeździe swoich zwolenników proklamował Chorwacką Republikę Chłopską, która — jego zdaniem — powstała 28 listopada w dzień wyborów do parlamentu konstytucyjnego.

${ }^{15}$ Đ. Stanković, Nikola Pašić i jugoslovensko pitanje, t. 2, Beograd 1985, s. 265.

${ }^{16}$ Konferencja założycielska Partii Demokratycznej odbyła się w dniach 15-16 lutego 1919 r. w Sarajewie.

${ }^{17}$ Dokumenti o Jugoslaviji: Historijat od osnutka zajedničke države do danas, opr. F. Čulinović, Zagreb 1968, s. 172. 
sytuacja sprzyjała podziałom frakcyjnym i możliwości secesji w obliczu narastających różnic ideologicznych ${ }^{18}$.

Dorobek legislacyjny parlamentu tymczasowego zamyka się liczbą 50 uchwalonych aktów prawnych. Wśród nich kluczową rolę odegrała ustawa o wyborze posłów do Sejmu Konstytucyjnego z 3 września 1920 r. Projekt ordynacji wyborczej do konstytuanty opracował rząd Ljube Davidovicia, który 29 sierpnia 1919 r. skierował go do parlamentu ${ }^{19}$. Niedługo potem nastąpiła półroczna przerwa w obradach parlamentu (15 września 1919-16 lutego 1920), a w konsekwencji nie prowadzono debaty nad projektem ustawy. Do porządku obrad projekt został wprowadzony w marcu 1920 r., ale faktycznie debata nad nim rozpoczęła się 12 czerwca 1920 r., a zakończyła się uchwaleniem ustawy 2 września $1920 \mathrm{r}$.

Ordynacja wyborcza z 1920 r. przyznawała obywatelom Królestwa SHS powszechne prawo głosu, a granice pełnoletniości określiła na 21. rok życia. Kandydatem na posła mogła być osoba, która potrafiła władać w mowie i w piśmie jednym z trzech języków urzędowych, przekroczyła 25. rok życia i co najmniej od 25 lat mieszkała na terytorium, które wchodziło w skład Królestwa SHS ${ }^{20}$. Biernego prawa wyborczego pozbawiono aktywnych oficerów, osoby odbywające służbę wojskową i urzędników państwowych. Zgodnie z art. 14 ordynacji wyborczej na każdej liście wyborczej powinien znajdować się co najmniej jeden kandydat $\mathrm{z}$ wykształceniem uniwersyteckim lub wyższym technicznym (kvalifikovani poslanik) ${ }^{21}$. Spełnienie tego warunku miało zagwarantować odpowiednie przygotowanie merytoryczne poselskiego gremium do prowadzenia debaty i przegłosowania konstytucji. Obowiązek umieszczania przez partie polityczne na listach kandydatów „kwalifikowanych” oznaczał zarazem możliwość utraty wygranego mandatu na rzecz przeciwników politycznych, na których listach znajdowały się osoby $\mathrm{z}$ wymaganym cenzusem wykształcenia, w przypadku niespełnienia tego warunku. Kraj został podzielony na 56 okręgów wyborczych, których granice zazwyczaj pokrywały się z granicami okręgów sądowych. Proporcjonalny system podziału mandatów preferował najsilniejsze partie, między które rozdzielano po wyborach $40 \%$ całości

${ }^{18}$ I. Miškulin, „Pribićevićevi ljudi” - Samostalna demokratska stranka u Slavoniji i Srijemu 1924-929, „Scrinia Slavonica” 2015, nr 15, s. 176.

${ }_{19}$ B. Balkovec, Izborno zakonodavstvo prve jugoslavenske države (1918.-1941.), „Časopis za Suvremenu Povijest" 2016, t. 48, nr 1, s. 199.

${ }^{20}$ Powszechne prawo wyborcze nie dotyczyło kobiet. Postulat przyznania kobietom praw wyborczych i nadania im przez to podmiotowości politycznej zgłaszali komuniści i socjaldemokraci, a także posłowie Chorwackiej Partii Ludowej i Słoweńskiej Partii Ludowej. Serbscy liberałowie opowiadali się za przyznaniem praw wyborczych tylko tym kobietom, których mężowie i synowie zginęli w czasie wojny. Największy sprzeciw kwestia ta wywołała w środowisku polityków radykalnych, którzy się obawiali się, że „politycznie niewyrobione kobiety” mogą stać się elektoratem partii rewolucyjnych. Większość posłów w głosowaniu opowiedziała się przeciwko przyznaniu praw wyborczych kobietom, postanowiono, że o tym zdecyduje konstytucja. Konstytucja widowdańska nie odniosła się do tej kwestii, a kobiety otrzymały prawo wyborcze w Jugosławii dopiero w 1945 r.; B. Balkovec, op. cit., s. 201.

${ }^{21}$ Wprowadzeniu obowiązku wysuwania kandydatów z wykształceniem uniwersyteckim sprzeciwiał się w toku dyskusji poseł republikański J. Prodanović, twierdząc, że jest to zapis niesprawiedliwy, skoro na 140 tys. wyborców przypada zaledwie jeden kvalifikovani poslanik; B. Balkovec, op. cit., s. 203. 
mandatów. Podział mandatów w wyborach miał preferować największe miasta: Belgrad (6 mandatów), Zagrzeb (5 mandatów) i Lublanę (4 mandaty $)^{22}$.

Dnia 28 listopada $1920 \mathrm{r}$. odbyły się pierwsze w dziejach państwa jugosłowiańskiego wybory powszechne posłów do konstytuanty. W ordynacji wyborczej przyjęto głosowanie w trybie tajnym poprzez wrzucanie przez wyborców gumowych kulek do urn wyborczych z nazwiskami kandydatów. Wybory, które odbyły się wcześniej w Chorwacji, polegały na pisemnym głosowaniu na listy wyborcze, na których znajdowały się nazwiska kandydatów. System przyjęty w 1920 r. powielał rozwiązania znane z Królestwa Serbii, gdzie wysoki poziom analfabetyzmu wymuszał stosowanie „procedury kulkowej”. Dla głosujących w Chorwacji nowością był także tajny tryb głosowania, którego nie znali w czasach austro-węgierskich ${ }^{23}$.

Tabela 1. Wyniki wyborów do Skupsztiny przeprowadzonych 20 listopada 1920 r.

\begin{tabular}{|l|c|c|}
\hline \multicolumn{1}{|c|}{ Nazwa partii } & Liczba głosów & \% oddanych głosów \\
\hline Partia Demokratyczna & 319448 & 19,88 \\
\hline Partia Radykalna & 284575 & 17,71 \\
\hline Chorwacka Republikańska Partia Chłopska & 230590 & 14,35 \\
\hline Komunistyczna Partia Jugosławii & 198736 & 12,36 \\
\hline Partia Rolników & 151603 & 9,43 \\
\hline Słoweńska Partia Ludowa & 111274 & 6,92 \\
\hline Jugosłowiańska Organizacja Muzułmańska & 110895 & 6,90 \\
\hline Partia Socjaldemokratyczna & 46792 & 2,91 \\
\hline Chorwacka Partia Ludowa & 38000 & 2,36 \\
\hline Narodowa Organizacja Turecka Cemijet & 30029 & 1,87 \\
\hline Wspólnota Chorwacka & 25867 & 1,61 \\
\hline Pozostałe ugrupowania & 59326 & 3,69 \\
\hline
\end{tabular}

Źródło: А. Фира, op. cit., s. 77-78.

Spośród 12706945 mieszkańców Królestwa SHS prawa wyborcze w 1920 r. miało 2480623 osób. W wyborach wzięło udział 1607265 osób (64,95\% uprawnionych). Do walki wyborczej stanęły 22 partie i ugrupowania polityczne. Wybory zmieniły układ sił politycznych, wprowadzając do parlamentu liczną reprezentację nowych stronnictw, reprezentujących interesy najliczniejszej warstwy społecznej — chłopstwa. Poważne straty zanotowała Partia Demokratyczna, którą wyborcy postrzegali przede wszystkim jako partię rządową, obciążając ją winą za problemy wewnętrzne państwa - gwałtowny

\footnotetext{
22 B. Balkovec, op. cit., s. 204.

23 Ibidem, s. 198. Do trybu jawnego powrócono dopiero w latach trzydziestych.
} 
wzrost cen i rozwój spekulacji, niesprawiedliwy system podatkowy, w którym ludność chłopska płacąca najniższe podatki była postrzegana jako grupa uprzywilejowana. Tylko w okręgu smederewskim Partii Demokratycznej udało się zachować pozycję dominującej sily politycznej ${ }^{24}$.

Zaskakująco dobry wynik w wyborach z 1920 r. osiągnęła partia komunistyczna, stając się czwartą siłą polityczną. W parlamencie tymczasowym środowiska lewicowe reprezentowało 13 posłów socjaldemokratycznych. Z czasem umiarkowani socjaldemokraci tracili wpływy polityczne na rzecz radykalnych środowisk socjalistycznych, którym bliskie stały się hasła rewolucji bolszewickiej. Ci ostatni zjednoczyli się na kongresie w Belgradzie (20-23 kwietnia 1919 r.), tworząc Socjalistyczną Robotniczą Partię Jugosławii ${ }^{25}$. Rosnąca popularność partii odwołującej się do wzorców bolszewickich spowodowała polityczną marginalizację socjaldemokratów, którym największe wpływy udało się zachować w Słowenii. Szeregi partii komunistycznej zasilali głównie przedstawiciele mniejszości etnicznych i narodowych (Bułgarzy, Turcy, Albańczycy, Węgrzy i Niemcy), ale także sfrustrowani niskim poziomem życia urzędnicy, a nawet byli właściciele ziemscy rozczarowani reformą rolną, i chłopi, których oburzały rosnące wciąż ceny towarów miejskich. W tym czasie liczebność partii sięgała 60 tys. członków. W 1920 r. podczas wyborów lokalnych komuniści potrafili uzyskać większość w radach ośmiu większych gmin w Chorwacji i 23 gmin w Serbii, choć inicjowane przez nich strajki zazwyczaj kończyły się niepowodzeniem.

Efektem nadmiernego zróżnicowania partii stał się pierwszy poważny rozłam, do którego doszło na kongresie w Vukovarze (22-24 czerwca 1920 r.). Większość delegatów opowiedziała się za zmianą nazwy partii na Komunistyczną Partię Jugosławii [dalej: KPJ], popierając dążenie do ustanowienia Sowieckiej Republiki Jugosławii ${ }^{26}$. Pierwotną, nieco skomplikowaną nazwę partii zachowali centryści (w większości Chorwaci). Pod koniec października 1920 r. centryści wydali manifest opowiadając się przeciwko bolszewizmowi i głosząc ,czysty marksizm”. Przed wyborami do konstytuanty opozycja zmniejszyła swoją aktywność ze względów taktycznych, ale na początku 1921 r. rozłam stał się faktem ${ }^{27}$.

W listopadowych wyborach poparcie dla KPJ było zróżnicowane w skali kraju, przy czym najwyższe notowano $\mathrm{w}$ okręgach pirockim i prizreńskim, gdzie skala poparcia dla partii przekraczała $30 \%{ }^{28}$. Z powodu fali strajków, a także aktów terroru przypisywanych komunistom i z powodu ich poparcia dla rewolucji bolszewickiej, 29 grudnia 1920 r. rząd wydał zarządzenie o zakazie propagandy bolszewickiej, co oznaczało w praktyce delegalizację KPJ, rewolucyjnych związków zawodowych

${ }^{24}$ М. Исић, Сељаштво у Србији 1918-1941, књ. 3: политички живот на селу, Београд 2015, s. 161,173 .

${ }_{25}$ F. Čulinović, Državnopravni razvitak Jugoslavije, Zagreb 1963, s. 160.

${ }^{26}$ H. Stys, Zarys historii politycznej Komunistycznej Partii Jugosławii (lata 1919-1929), „Historia i Polityka" 2008, t. VII, s. 132-133.

${ }_{27}$ J. Pirjevec, Jugoslavija. Nastanek, razvoj ter razpad Karadjordjevićeve in Titove Jugoslavije, Koper 1995, s. 22.

${ }^{28}$ W okręgu pirockim KPJ odniosła zwycięstwo, zdobywając 36,2\% głosów; М. Исић, op. cit., s. 164. 
i organizacji młodzieży komunistycznej. Na podstawie tej decyzji zostały zamknięte wszystkie organizacje robotnicze, a ich biura i kasy zostały opieczętowane. Na próbę zamachu na regenta Aleksandra 29 czerwca 1921 r. i zabójstwo urzędującego ministra spraw wewnętrznych Milorada Draškovicia, 21 lipca 1921 r. rząd odpowiedział wprowadzeniem dekretu o ochronie bezpieczeństwa publicznego i porządku w państwie" (Zakon o zaštiti države, Obznana) ${ }^{29}$. Dekret wszedł w życie 3 sierpnia 1921 r., a już następnego dnia parlament anulował mandaty posłów komunistycznych, tym samym zmuszając ich do opuszczenia parlamentu. Na procesie w sprawie zamachu na regenta osądzonych zostało 19 byłych deputowanych $\mathrm{KPJ}^{30}$.

\section{KONSTYTUCJA WIDOWDAŃSKA}

Pierwsze posiedzenie konstytuanty wyznaczono na 12 grudnia $1920 \mathrm{r}$. w budynku starego konaku, który w 1919 r. został adaptowany w pośpiechu na potrzeby obrad ${ }^{31}$. Dwukondygnacyjny konak zbudowany w początkach XX w. w czasie wojny służył jako austriacki szpital polowy. Umieszczenie Skupsztiny w konaku miało być rozwiązaniem doraźnym, do chwili oddania do użytku gmachu godnego parlamentu zjednoczonego państwa $^{32}$. W prostokątnej sali obrad plenarnych, na wprost wejścia umieszczono prezydium i stół stenografów, a jej przestrzeń wypełniały długie ławy, w których zasiadali posłowie. W czasie obrad parlamentu panował chaos, czemu sprzyjała ciasnota sali, w której odbywały się obrady. Konieczność przeciskania się do swoich miejsc w ławach poselskich powodowała, że część posłów nie zajmowała swojego miejsca tylko otaczała trybunę. Rozmieszczenie partii na sali nie przebiegało według przyjętego podziału na lewicę i prawicę, co powodowało, że posłowie skrajnie skonfliktowanych ze sobą ugrupowań zasiadali w sąsiednich rzędach. Obrady zakłócały niejednokrotnie głośne spory między katolickimi księżmi ze Słowenii i zasiadającymi w sąsiedniej ławie socjalistami. Kiedy głośne krzyki zagłuszały prowadzącego obrady przewodniczącego, ten próbował poskramiać niesfornych posłów używając elektrycznego dzwonka. Aby zapewnić odpowiednią frekwencję na sali plenarnej, wprowadzono zasadę odbierania diet poselskich tym, którzy nie stawili się na sesję $e^{33}$.

29 Zamachu dokonał młody komunista z Bośni, związany z organizacją Crvena Pravda, A. Alijagić, skazany za ten czyn na karę śmierci. KPJ oficjalnie potępiła zamach; vide J.P. Newman, Post-Imperial and Post-war Violence In the South Slav Lands, 1917-1923, „Contemporary European History” 2010, t. 19, nr 3, s. 263.

${ }^{30}$ Od 1921 r. jugosłowiańscy komuniści kontynuowali działalność w sposób nielegalny, a Biuro Polityczne KPJ przeniosło się do Wiednia; vide М.-Ж. Чалић, Историја Југославије у 20. веку, Београд 2010, s. 116-117.

31 А. Фира, op. cit., s. 25.

32 W 1928 r. siedzibę parlamentu przeniesiono do pochodzącego z lat 30. XIX w. budynku koszar wojskowych. Budowę obiektu, który miał stać się siedzibą parlamentu zjednoczonej Jugosławii rozpoczęto na początku lat dwudziestych XX w., ale w 1929 r. jego budowę przerwano, aby wznowić ją w 1935 r. Rok później budynek stał się formalnie siedzibą parlamentu jugosłowiańskiego; vide Д. Ћирић, Градски номад - београдски записи фоторепортера Александра Аие Симића, Београд 2011, s. 305-306.

33 S. Roszkowski, S.H.S. Szkice z Jugosławji, Warszawa 1921, s. 66. 
Jednym z zasadniczych problemów spornych w debacie nad kształtem konstytucji stała się kwestia parlamentu jednoizbowego. W kwietniu 1921 r. premier Nikola Pasić opowiadał się za parlamentem dwuizbowym, który nie uzyskał akceptacji i ostatecznie w konstytucji znalazł się przepis o parlamencie jednoizbowym ${ }^{34}$. Nowa ustawa zasadnicza została uchwalona przez parlament w dniu św. Wida 28 czerwca 1921 r., (stąd nazwa widowdańska), w rocznicę bitwy na Kosowym Polu w 1389 r. Data została wybrana nieprzypadkowo, gdyż Widowdan zajmował kluczową pozycję w serbskiej narracji historycznej, a także w roku liturgicznym Serbskiego Kościoła Prawosławnego. Za przyjęciem konstytucji głosowało 223 posłów, a przeciw 35 (w tym 21 posłów partii Radicia). Aż 156 deputowanych zbojkotowało głosowanie. W tej grupie byli komuniści, posłowie partii Radicia, ale także inni deputowani chorwaccy. Projekt konstytucji poparli demokraci, radykałowie i Słoweńska Partia Ludowa ${ }^{35}$.

Nowa konstytucja składała się 14 części i 142 artykułów. Dokument określał Królestwo Serbów, Chorwatów i Słoweńców jako dziedziczną monarchię parlamentarną, pod panowaniem dynastii Karađorđeviciów ${ }^{36}$. Art. 55 konstytucji widowdańskiej gwarantował nietykalność osobie króla, a także zakaz pociągania go do odpowiedzialności i prowadzenia przeciwko niemu dochodzeń z tytułu wykonywania przez niego czynności państwowych. Zgodnie z konstytucją monarcha władzę ustawodawczą dzielił z parlamentem, wykonawczą z rządem, sądowniczą zaś sprawowały sądy działające w imieniu króla i na podstawie ustaw. Monarcha zwoływał i rozwiązywał jednoizbowy parlament, podpisywał ustawy i umowy międzynarodowe, był naczelnym wodzem sił zbrojnych, powoływał i odwoływał premiera, członków rządu i wyższych urzędników państwowych. Przewagę króla w procesie legislacyjnym określał fakt, że chociaż prawo do zgłaszania wniosków ustawodawczych miał każdy poseł, to jednak projekty ustaw przedkładała z upoważnienia króla rada ministrów lub poszczególni ministrowie. Każda ustawa przegłosowana przez parlament, aby mogła wejść w życie, musiała być zatwierdzona przez monarchę i ogłoszona $\mathrm{w}$ formie dekretu. Teoretycznym ograniczeniem władzy króla był wymóg kontrasygnaty przez jednego z ministrów wszystkich aktów wydanych przez władcę. Zarówno jednak premier rządu, jak też ministrowie byli powoływani na mocy nominacji królewskich i bezpośrednio mu podlegali. Nierównoprawny układ stosunków między królem a parlamentem określało przypisane monarsze prawo zwoływania obrad parlamentu. Król mógł zwołać parlament w dowolnym terminie, jeśli tylko uznał, że wymaga tego dobro państwa, nawet w sytuacji, kiedy sama Skupsztina zdecydowała o odroczeniu obrad ${ }^{37}$.

34 S. Starzyński, Współczesny ustrój prawno-polityczny Polski i innych państw słowiańskich, Warszawa 2010, s. 98.

35 Partia powstała w 1892 r. jako Katolicka Partia Narodowa (Katolicka Nacjonalna Stranka), w 1905 r. została przemianowana na Słoweńską Partię Ludową (Slovenska Ljudska Stranka). Na jej czele stał A. Korošec.

${ }^{36}$ Српски устави од 1835. до 1990. Године са уставима Краљевине СХС и Краљевине Југославије, орr. М. Радојевић, Београд 2004, s. 191.

37 Konstytucja widowdańska nawiązywała do wzorca ustrojowego państwa serbskiego sprzed 1914 r. Po zamordowaniu ostatniego przedstawiciela dynastii Obrenoviciów w 1903 r. porządek konstytucyjny 
Zgodnie z konstytucją jednoizbowa Skupsztina należała obok króla i rządu do trzech najważniejszych organów państwa. Parlament narodowy miał być wyłaniany w wyborach czteroprzymiotnikowych: powszechnych, równych, bezpośrednich i tajnych na cztery lata. Konstytucja ustanawiała powszechne prawo wyborcze dla mężczyzn, z wyjątkiem osób aktualnie służących w wojsku oraz osób skazanych. Zgodnie z art. 74 konstytucji wyborcy nie mieli prawa wysuwania żądań pod adresem posłów, a ci nie mogli przyjmować mandatów nakazczych. W myśl tego przepisu podmiotem reprezentacji stawał się naród jako byt idealny, a nie realnie istniejące społeczeństwo ${ }^{38}$.

Władza wykonawcza została powierzona radzie ministrów, powoływanej przez króla. Rząd odpowiadał przed królem i przed Skupsztiną. Konstytucja zapewniała Skupsztinie prawo do kontaktów z poszczególnymi ministrami, ale nie z radą ministrów in corpore. Posłom zagwarantowano prawo kierowania pytań oraz interpelacji do poszczególnych ministrów, na których ciążył obowiązek udzielenia na nie odpowiedzi w określonym terminie. Ministrowie mieli prawo wydawania rozporządzeń z mocą ustawy, ale parlament mógł takie akty prawne pozbawić mocy obowiązującej w całości lub w części. Najpóźniej miesiąc przed rozpoczęciem październikowej sesji Skupsztiny rząd został zobowiązany do przedłożenia preliminarza budżetowego na następny rok. Parlament przed uchwaleniem budżetu rocznego mógł uchwalać budżety miesięczne (tzw. dwunastki) ${ }^{39}$.

W opinii Ferdo Čulinovicia podstawą funkcjonowania systemu parlamentarnego jest spełnienie trzech warunków: zapewnienie parlamentowi autonomii i wyłącznego prawa do uchwalania budżetu państwa, a także zapewnienie większości parlamentarnej rządowi aktualnie sprawującemu władzę ${ }^{40}$. W konstytucji widowdańskiej autonomia parlamentu była zabezpieczona gwarancjami, że parlament narodowy sam określa swój tryb pracy, a także wybiera swoje prezydium. Zgodnie z konstytucją parlament miał prawo zbierać się każdego roku na posiedzeniu regularnym 20 października. Za ograniczenie autonomii można uznać przepis, że to władca zgodnie z konstytucją miał prawo zwoływać i rozwiązywać parlament dekretem, a więc mógł parlamentowi uniemożliwić pracę nawet wbrew woli większości posłów. Čulinovic określa taką sytuację prawną mianem ograniczonej autonomii parlamentu. W konstytucji określono, że w dekrecie

w państwie serbskim aż do wybuchu I wojny światowej określała znowelizowana ustawa zasadnicza z 1888 r. Zgodnie z jej przepisami władza wykonawcza w państwie należała do króla i ośmiu ministrów, a ustawodawcza do króla i parlamentu (Skupsztiny). W parlamencie zasiadało 160 posłów, wybieranych na trzy lata w wyborach powszechnych. Prawo głosu mieli wszyscy pełnoletni Serbowie po ukończeniu 21. roku życia, płacący co najmniej 15 dinarów podatków bezpośrednich. Pozbawieni prawa głosu byli oficerowie i żołnierze. Wybranym na posła może być każdy Serb mający 30 lat i płacący 60 dinarów podatków bezpośrednich, umiejący czytać i pisać. Urzędnicy państwowi, księża i wójtowie gmin nie mogli być wybierani do parlamentu. Vide М.Д. Пешић, Б.Б. Младеновић, Функционисање парламентарног система у Краљевини Србији од 1889. до 1892. Године, „Историјски часопис” 2016, nr 65, s. 331-353.

38 E. Mizerski, Jugosłowiański system przedstawicielski 1918-1990 (w zarysie), Toruń 1999, s. 30; А. Фира, op. cit., s. 204.

39 S. Starzyński, op. cit., s. 200.

${ }^{40}$ F. Culinović, op. cit., s. 186. 
króla o rozwiązaniu parlamentu musi być zawsze wskazany termin wyborów do kolejnego parlamentu.

Parlament uzyskał prawo samodzielnego podejmowania decyzji o rocznym budżecie i tylko on debatował i decydował o korektach budżetu. Rząd miał możliwość, aby przedłużyć realizację budżetu najwyżej o cztery miesiące. Rządy parlamentarnej większości nie były wprost przewidziane w konstytucji widowdańskiej, ale zależność rządu od parlamentu wynikała z przepisów o politycznej odpowiedzialności rządu przed parlamentem. Z czasem w sposób widoczny wzrastała odpowiedzialność rządu przed królem, a zarazem — szczególnie od końca 1926 r. — słabła wobec parlamentu. Polityczna odpowiedzialność rządu przed parlamentem nadal istniała w teorii, ale była ograniczona odpowiedzialnością rządu wobec władcy. Zgodnie z konstytucją Królestwo SHS stawało się państwem centralistycznym z ograniczonym samorządem lokalnym, a jeśli chodzi o system rządów - dziedziczną monarchią z parlamentaryzmem ograniczonym przez decyzje władcy. Ferdo Čulinović definiował tego typu ustrój, jako „ukryty absolutyzm" (prikriveni absolutizam $)^{41}$.

W państwie coraz większą rolę odgrywał suweren. Spośród 24 rządów sprawujących władzę w latach dwudziestych tylko dwa upadły w wyniku wotum nieufności, pozostałe zmienił władca, korzystając z przysługujących mu konstytucyjnych uprawnieńt ${ }^{42}$. W tym czasie prawie wszyscy premierzy, ale także większość ministrów i najwyższych urzędników państwowych była Serbami.

Tabela 2. Skład Skupsztiny w latach 1920-1927 (liczba mandatów)

\begin{tabular}{|l|r|r|r|r|}
\hline \multicolumn{1}{|c|}{ Partia } & 1920 & 1923 & 1925 & 1927 \\
\hline Narodowa Partia Radykalna & 91 & 108 & 143 & 112 \\
\hline Partia Demokratyczna & 92 & 51 & 37 & 61 \\
\hline Chorwacka Partia Chłopska & 50 & 70 & 67 & 50 \\
\hline Słoweńska Partia Ludowa & 27 & 24 & 21 & 21 \\
\hline Jugosłowiańska Organizacja Muzułmańska & 24 & 18 & 15 & 17 \\
\hline Komunistyczna Partia Jugosławii & 58 & - & - & - \\
\hline Partia Agrarna (Zemlioradnicy) & 39 & 11 & 3 & 9 \\
\hline Partia Džemijet & 88 & 14 & - & - \\
\hline Partia Niemiecka & - & 8 & 5 & 6 \\
\hline Pozostali & 29 & 9 & 24 & 28 \\
\hline Łącznie & 419 & 313 & 315 & 326 \\
\hline
\end{tabular}

Źródło: S. Ramet, The Three Yugoslavias. State-building and Legitimation, 1918-2005, Washington 2006, s. 55-71.

${ }^{41}$ F. Čulinović, op. cit., s. 187.

${ }^{42}$ C. Antić, Kratka istorije Srbije 1804-2004, Belgrad 2005, s. 155-156. 
W sporze o koncepcję organizacji wewnętrznej państwa ścierały się ze sobą dwie tendencje: unitarystyczna prowadząca do centralizmu, i federalistyczna. Orientacji centralistycznej pozostał wierny dwór królewski, dwie największe partie serbskie — radykalna i demokratyczna, Jugosłowiańska Organizacja Muzułmańska, a także partie socjaldemokratyczne i komunistyczna. Zwolennikami federalizmu byli przede wszystkim posłowie Chorwackiej Republikańskiej Partii Chłopskiej, a także posłowie katoliccy skupieni w Klubie Narodowym Wspólnoty Chorwackiej. W 1920 r. Stjepan Radić opowiadał się za federacją, w której relacje pomiędzy Serbią, a Chorwacją przypominałyby relacje w dualistycznej monarchii austro-węgierskiej ${ }^{43}$. Przejmowanie władzy nad Chorwacją przez gubernatorów, mianowanych przez Belgrad, zgodnie z konstytucją spowodowało bojkot prac parlamentarnych przez posłów Radicia.

Wewnętrzne konflikty w Skupsztinie wynikały także z odmiennych doświadczeń politycznych. Obstrukcja parlamentarna była częstą praktyką polityków chorwackich, zasiadających niegdyś w sejmie węgierskim, ale wielu polityków serbskich traktowało ją jako zdradę państwa. Jednocześnie serbskie skłonności centralistyczne wielu Chorwatów postrzegało jako dążenie do hegemonii. Pierwsza kulminacja kryzysu politycznego nastąpiła wiosną 1924 r. Największe ugrupowanie opozycyjne Chorwacka Republikańska Partia Chłopska, po zdobyciu 70 mandatów w wyborach w 1923 r. podjęło rozmowy ze Słoweńską Partią Ludową i Jugosłowiańską Organizacją Muzułmańską [dalej: JOM] w celu stworzenia wspólnego frontu przeciwko centralizacji państwa. Równolegle narastał kryzys wśród blisko współpracujących dotąd ze sobą partii serbskich. Partia Demokratyczna zaczęła szukać nowych sojuszników w szeregach partii słoweńskiej i JOM. Tworzący się tym samym Blok Opozycyjny stanowił poważne zagrożenie dla istniejącego ładu politycznego, a zwłaszcza dla Serbskiej Partii Radykalnej i jej przywódcy Nikoli Pašicia. Cieszący się ogromnym autorytetem polityk zdołał namówić króla Aleksandra do zawieszenia obrad parlamentu i zapowiedzi jego ponownego zwołania w listopadzie 1924 r. Niechęć króla do przywódcy Partii Radykalnej wydawała się znacznie mniejsza niż skłonność do popierania rosnącej w siłę partii chorwackiej, głoszącej hasła republikańskie i federalistyczne. W lutym 1925 r., zaledwie kilka dni przed planowanymi wyborami parlamentarnymi Stjepan Radić został aresztowany na podstawie ustawy o ochronie państwa ${ }^{44}$. W obliczu zagrożenia delegalizacją Chorwacka Republikańska Partia Chłopska uznała zasady konstytucji widowdańskiej i panowanie dynastii Karađorđeviciów, powracając do ław parlamentarnych. Sam Radić wszedł do rządu i przez 17 miesięcy kierował resortem oświaty.

${ }^{43}$ A. Bellamy, The Formation of Croatian National Identity. A Centuries Old Dream?, Manchester-New York 2003, s. 49.

${ }^{44}$ Podstawowym zarzutem przeciwko Radiciowi była deklaracja akcesji jego partii do Międzynarodówki Chłopskiej (Krestinernu), w czasie wizyty w Moskwie w 1924 r.; I. Banac, With Stalin Against Tito. Cominformist Splits in Yugoslav Communism, New York 1988, s. 58. 


\section{SKUPSZTINA ZEMSTY}

W grudniu 1926 r. zmarł Nikola Pašić, który przez trzy dekady odgrywał wiodącą rolę w serbskim życiu politycznym ${ }^{45}$. Jego śmierć stanowiła symboliczną cezurę upadku kruchej równowagi politycznej. Przestał istnieć rząd wspierany przez Chorwacką Partię Chłopską, a ona sama w wyborach w 1927 r. zanotowała wyborczą porażkę, zdobywając zaledwie 50 mandatów. Do grona zwolenników federalizmu po wyborach dołączyła nowa siła polityczna Niezależna Partia Demokratyczna Svetozara Pribićevicia, tworząc wspólnie z Chorwacką Partią Chłopską opozycyjną Koalicję Chłopsko-Demokratyczną (Seljačko-Demokratska Koalicija). Celem Koalicji miała być rewizja konstytucji, a także ograniczenie dominacji politycznej Serbskiej Partii Radykalnej. Sojusz Pribičevicia i Radicia wskazywał, że linia podziału politycznego nie pokrywa się z podziałem etnicznym, ale przebiega także wewnątrz społeczności serbskiej ${ }^{46}$. Atmosferę sporów politycznych podgrzał sam Pribićević prowokacyjną wypowiedzią, że w państwie austro-węgierskim było więcej swobód obywatelskich niż w Królestwie SHS ${ }^{47}$. Po wyborach w 1927 r. Koalicja Demokratyczno-Chłopska dysponowała na tyle dużą liczbą mandatów, aby móc skutecznie blokować działania rządu, kierowanego wówczas przez Velimira Vukičevicia.

Prawodawcza aktywność parlamentu była coraz bardziej spychana na drugi plan wobec sporów o skład kolejnych rządów. Agresywny ton dyskusji politycznych, często dwołujących się do stereotypów narodowościowych zdominował obrady parlamentu, utrudniając konsekwentną realizację polityki zjednoczeniowej. Projekty ustaw o reformie agrarnej, o zjednoczeniu systemów prawnych i podatkowych, o samorządach, o systemie szkolnym były odkładane z roku na rok. W coraz większym stopniu państwem zarządzano za pomocą dekretów ministerialnych i uchwał bez podstaw prawnych.

W czerwcu 1928 r. kolejne wystąpienia w parlamencie dwóch charyzmatycznych przywódców Koalicji Chłopsko-Demokratycznej - Stjepana Radicia i Svetozara Pribičevicia - budziły skrajne emocje i wrogość wśród zwolenników Partii Radykalnej. Milan Stojadinović wspominając debaty w 1928 r. zwracał uwagę na to, że Serbowie wspominali z rozrzewnieniem przedwojenną Skupsztinę, w której nie dochodziło do gorszących scen, nie obrzucano się wyzwiskami i nie zakłócano wypowiedzi przeciwników politycznych, jak w parlamencie SHS ${ }^{48}$. Wydawane w Belgradzie pismo „Jedinstvo”, związane ze sferami rządowymi otwarcie zachęcało do zamordowania

45 Vide szerzej M. Dymarski, Nikola Pašić (1845-1926) - serbski radykalny konserwatysta, „Studia Środkowoeuropejskie i Bałkanistyczne" 2016, nr XXIV, s. 45-57.

${ }^{46}$ Koalicję Chłopsko-Demokratyczną określano także potocznym określeniem prečanski front. Pojęcie prečan pochodziło od słowa preko i obejmowało Serbów i przedstawicieli innych słowiańskich grup etnicznych, którzy w przeszłości żyli na terytoriach należących do Austro-Węgier; vide Ch. Nielsen, Making Yugoslavs. Identity in King Aleksandar's Yugoslavia, Toronto 2014, s. 72.

${ }_{47}$ R.W. Seton-Watson, The Background of the Jugoslav Dictatorship, ,The Slavonic and East European Review" 1931, t. 10, nr 29, s. 368.

${ }^{48}$ M. Stojadinović, Ni rat ni pakt. Jugoslavija između dva rata, Rijeka 1970, s. 252. 
czołowych polityków koalicjii ${ }^{49}$. Kłótnie polityczne doprowadziły do katastrofy w czasie sesji parlamentu 20 czerwca 1928 r. Poseł Punisa Račić zadeklarował się jako „Serb, który dostrzega zagrożenie narodu i ojczyzny", grożąc, że sięgnie po broń by chronić interesy Serbów ${ }^{50}$. Po tych słowach wystrzelił pięć kul w kierunku posłów chorwackiej partii chłopskiej. Na Sali obrad zmarło dwóch przedstawicieli Chorwackiej Partii Chłopskiej (Pavle Radić i Đura Basariček), ciężko raniono trzech posłów, w tym przywódcę partii Stjepana Radicia, który zmarł 8 sierpnia 1928 r..$^{51}$

Wydarzenia w Skupsztinie wywołały falę protestów i manifestacji na terenie Chorwacji i doprowadziły do kryzysu rządowego. Komunikacja między rządem a opozycją została całkowicie przerwana. 83 posłów Koalicji Chłopsko-Demokratycznej opuściło Belgrad, udając się do Zagrzebia i stamtąd domagało się nowych wyborów i rewizji konstytucji. Z inicjatywy następcy Radicia - Vladko Mačka - zaczęto tworzyć formacje paramilitarne, złożone z byłych oficerów armii habsburskiej, które miały chronić czołowych działaczy partii chorwackiej ${ }^{52}$. Pod koniec roku Zagrzeb stał się sceną demonstracji antyserbskich, które 1 grudnia 1928 r. przerodziły się w zamieszki, a te pochłonęły 12 ofiar śmiertelnych ${ }^{53}$. Przedłużający się kryzys polityczny obniżał prestiż państwa jugosłowiańskiego, ale także zagrażał postępującym procesem decentralizacji władzy, co w konsekwencji mogło doprowadzić do rozpadu Królestwa SHS.

\section{DYKTATURA KRÓLEWSKA}

Dnia 6 stycznia 1929 r. ogłoszono manifest Aleksandra Karađorđevicia wraz z dekretem o władzy królewskiej i państwowej, na mocy którego konstytucja widowdańska została zniesiona. Parlament rozwiązano, a pełnię władzy ustawodawczej i wykonawczej przejął król. Kilka dni później została zakazana działalność wszystkich partii politycznych i stowarzyszeń opartych na ,plemiennej” czyli narodowościowej podstawie. W wydanym dekrecie monarcha działał przeciwko porządkowi konstytucyjnemu, nie określając terminu wyborów do nowej izby. Zawieszenie przez władcę konstytucji w 1929 r., rozwiązanie parlamentu i nierozpisanie wyborów do nowej parlamentu spowodowało, że król skupił w swoich rękach całą władzę państwową, zyskał prawo

49 Dnia 14 czerwca 1928 r. ukazał się artykuł Sa svinjama može se samo njihovim jezikom razgovarati (Ze świniami można rozmawiać tylko w ich języku), który zabójstwo Pribičevicia i Radicia „,najlepiej w tym samym dniu" uznawał za patriotyczny obowiązek.

50 M.J. Zacharias, Polityka KPJ i kwestia narodowościowa w Jugosławii w latach 1919-1943, ,Studia z Dziejów Rosji i Europy Środkowo-Wschodniej” 2004, nr XXXIX, s. 48.

51 Zamachowiec P. Račić pochodził z Czarnogóry i w 1927 r. został po raz pierwszy wybrany do parlamentu. Po zamachu Račić opuścił bez przeszkód gmach parlamentu i sam następnego dnia zgłosił się na policję. Został osądzony, skazany na 12 lat więzienia i umieszczony w obszernej willi niedaleko Pożarevaca. Opuścił swoje „więzienie” w kwietniu 1941 r. i powrócił do Belgradu. E. Despalatović, The Roots of the War in Croatia, [w:] Neighbours at War. Anthropological Perspectives on Yugoslav Ethnicity, Culture and History, red. J.M. Halpern, Pennsylvania 2000, s. 87.

52 J.P. Newman, op. cit., s. 264.

53 S.K. Pavlowitch, Serbia. The History Behind the Name, London 2002, s. 126. 
wydawania ustaw bez kontrasygnaty ministra i to bez ponoszenia odpowiedzialności z powodu podejmowanych działań. Na czele nowego rządu stanął dowódca gwardii królewskiej — gen. Petar Żivković.

Monarcha uzasadnił swoją decyzję tym, że nadszedł czas, kiedy „ślepe polityczne emocje zniszczyły system parlamentarny". Jak napisał w proklamacji skierowanej do narodu: ,„...] jest moim świętym obowiązkiem, żebym za pomocą wszystkich dostępnych środków utrzymał państwową i narodową jedność. Jestem zdecydowany, by bez wahania wypełnić do końca ten obowiązek" ${ }^{\prime 54}$. W imię jugosłowiańskich haseł unitarystycznych monarcha sam za pomocą środków autorytarnych próbował siłą urzeczywistnić niezrealizowaną do tej pory integrację. Naruszeniem konstytucji stało się także jej zawieszenie w 1929 r. w sposób, który naruszał istniejący porządek prawny. Art. 125 konstytucji określał możliwość wprowadzenia zmian ustawy zasadniczej poprzez wspólną decyzję króla i Skupsztiny. Konstytucja z 1921 r. nie zawierała przepisów, które umożliwiałyby monarsze samodzielną zmianę tekstu ustawy zasadniczej, a tym bardziej jej zawieszenie, co więcej, art. 58 nakładał na władcę obowiązek przestrzegania nienaruszalności konstytucji i panowania zgodnie z jej postanowieniami.

Potwierdzeniem pozycji ustrojowej króla była konstytucja oktrojowana z $1931 \mathrm{r}$. Nowe państwo przyjęło nazwę Królestwo Jugosławii, a jego ustrój określono jako „monarchię dziedziczną i konstytucyjną". Symbolicznym przejawem marginalizacji parlamentu stało się usunięcie z nowej ustawy zasadniczej pojęcia „monarchia parlamentarna", używanego w konstytucji widowdańskiej. Jednoizbowy parlament przekształcono w dwuizbowe Przedstawicielstwo Narodowe, składające się ze Zgromadzenia Narodowego i Senatu. Zachowując zasadę, że posłowie reprezentują naród, zobowiązano ich w nowej ustawie zasadniczej do złożenia przysięgi wierności wobec króla ${ }^{55}$. W latach 1931, 1935 i 1938 zostały przeprowadzone kolejne wybory parlamentarne. Głosowanie odbywało się w trybie jawnym, a każdy z głosujących deklarował przed komisją wyborczą, na kogo zamierza głosować.

Wprowadzenie ustroju autorytarnego nie doprowadziło do wyciszenia konfliktów politycznych i konsolidacji państwa. W świecie polityki rozpoczął się okres wendety. Jeden z twórców państwa jugosłowiańskiego, Svetozar Pribičević, został aresztowany wiosną 1929 r., a potem dzięki interwencji czechosłowackiego prezydenta Tomáša Masaryka wypuszczony z więzienia i zmuszony do emigracji. W kwietniu 1929 r. na granicy austriacko-jugosłowiańskiej zginęło dwóch działaczy komunistycznych Đuro Đaković i Nikola Haćimovićs6. Na początku 1931 r. dwóch agentów policji zamordowało chorwackiego historyka i antropologa Milana Sufflaya. Za krytykę polityki Aleksandra I kilku znanych polityków zostało internowanych: Vladko Maček został zesłany do miejscowości Čajniče, a Anton Korošec do Vrnjačkiej Banji, a następnie na wyspę Hvar.

${ }_{54}^{54}$ H.F. Armstrong, The Royal Dictatorship in Yugoslavia, „Foreign Affairs” 1929, t. 7, nr 4, s. 600-601.

${ }_{55}$ Српски устави од 1835. до 1990..., s. 238.

${ }^{56}$ D. Bojković, The Communist Party of Yugoslavia during the Autocratic Rule of King Aleksandar Karađorđević, ,Tokovi Istorije” 2015, nr 3, s. 69. 
W październiku 1934 r. w czasie wizyty w Marsylii król Aleksander I Karađorđević zginął z rąk chorwackich i macedońskich ekstremistów. Śmierć władcy nie przyniosła zasadniczych zmian w funkcjonowaniu państwa jugosłowiańskiego, a jego następca - namiestnik Paweł Karađorđević kontynuował politykę kuzyna. Dopiero 26 sierpnia 1939 r. między przywódcą Chorwackiej Partii Chłopskiej V. Mačkiem i nowym premierem Dragišą Cvetkoviciem zostało zawarte porozumienie (sporazum), które doprowadziło do powstania odrębnej chorwackiej jednostki administracyjnej (banowiny). Włączono do niej także kilka okręgów Bośni i Hercegowiny. Zawarcie porozumienia nie doprowadziło do uspokojenia sytuacji w państwie i wygaszenia napięć o podłożu narodowościowym, ponieważ nastąpiło zbyt późno. Porozumienia Maček-Cvetković nie akceptowały ani kręgi nacjonalistyczne w Serbii, ani chorwaccy separatyści ${ }^{57}$.

Parlamentarny system ustanowiony na mocy konstytucji z 1921 r. okazał się nieefektywny, jeśli chodzi o uzyskanie politycznego konsensu, a do jego realizacji nie dojrzały ugrupowania polityczne, którym trudno było wydostać się z pułapki lokalnych (regionalnych) interesów. Mimo deklaracji o budowie jednego „narodu jugosłowiańskiego”, w praktyce klasę polityczną Królestwa SHS cechowały postawy prymordialne, skłaniające do nieufności wobec „ludzi nowych” w polityce. Pierwszy premier Królestwa Stojan Protić żalił się jednemu ze swoich przyjaciół w 1922 r., że serbscy politycy kilka lat przed zjednoczeniem znali zaledwie kilkunastu słoweńskich i chorwackich polityków i dopiero wojna zmusiła ich do współpracy ${ }^{58}$.

Dziesięcioletnie dzieje Królestwa SHS stanowią przykład trudności, jakich doświadczały państwa bałkańskie w procesie tworzenia państw wielonarodowych i wieloetnicznych. Królestwo SHS od początku borykało się z problemem zróżnicowania narodowościowego, religijnego i cywilizacyjnego. Na wchodzących w jego skład terytoriach przed $1914 \mathrm{r}$. funkcjonowały odmienne systemy prawne $\mathrm{i}$ administracyjne, a do tego państwo borykało się z kryzysem gospodarczym wywołanym wojną. Przedłużający się kryzys parlamentarny prowadzący do dyktatury królewskiej także nie stanowił sytuacji wyjątkowej w skali regionu. Cztery lata rządów parlamentarnych w Albanii (1920-1924) doprowadziły do destabilizacji politycznej i przejęcia pełni władzy w 1925 r. przez Ahmeda Zogu, który w 1928 r. ogłosił się królem Albańczyków, podporządkowując sobie wszystkie organy władzy centralnej. W Bułgarii przedłużający się kryzys rządowy i trudności sformowania stabilnego rządu doprowadziły w 1934 r. do zamachu stanu i przejęcia władzy przez grupę oficerów, których dwa lata później pozbawił władzy car Borys III, rozwiązując wszystkie działające w tym kraju partie polityczne. Brak stabilności politycznej i narastający kryzys gospodarczy skłoniły do podjęcia podobnego kroku w 1938 r. władcę Rumunii - Karola II. Wyjątek wśród bałkańskich dyktatur królewskich stanowił „reżim 4 sierpnia”, jak określano od $1936 \mathrm{r}$. dyktaturę Ioannisa Metaxasa w Grecji, który jako premier rządu przejął pełnię władzy w kraju za aprobatą króla Jerzego II.

\footnotetext{
57 D. Djokić, Elusive Compromise. A History of Interwar Yugoslavia, New York 2007, s. 212-222.
}

${ }^{58}$ C. Antić, Kratka istorija Srbije 1804-2004, Beograd 2005, s. 155-156. 
Królewskie dyktatury na Bałkanach nawiązywały do widocznej w Europie lat trzydziestych tendencji do przemian ustrojowych w duchu autorytarnym, aczkolwiek przypisywanie dominującej roli ustrojowej monarchom odróżniały Bałkany od wzorców zachodnioeuropejskich. Stanowiły one prostą konsekwencję niepowodzenia budowy społeczeństwa obywatelskiego i braku nowoczesnych partii politycznych, zbudowanych na podstawie ideowej, a nie tylko wyrażających partykularne interesy ${ }^{59}$. Królewskie dyktatury okazały się rozwiązaniem doraźnym i nie mogły odwoływać się do znaczącego poparcia ze strony społeczeństwa. W przypadku Jugosławii próba nadania dyktaturze królewskiej pozorów monarchii parlamentarnej doprowadziła do utworzenia partii reżimowych (Jugosłowiańska Partia Narodowa, Jugosłowiańska Wspólnota Radykalna), które miały zdominować scenę polityczną po wyeliminowaniu z niej partii działających w latach 1919-1929. W praktyce partie reżimowe pozostały formacjami heterogenicznymi, niesamodzielnymi i nie mogły stanowić realnej konkurencji dla nielegalnych sił politycznych. Dziesięcioletni okres istnienia Królestwa SHS pozostał w pamięci Jugosłowian jako okres chaosu i destabilizacji wywołanej przez pozostawienie podmiotom politycznym możliwości swobodnego działania i stwarzał dość powszechne przekonanie o konieczności budowy parlamentaryzmu „kontrolowanego” przez organy władzy wykonawczej.

\section{BIBLIOGRAFIA}

ŹRÓDŁA

Dokumenti o Jugoslaviji: Historijat od osnutka zajedničke države do danas, opr. F. Čulinović, Školska Knjiga, Zagreb 1968.

Maček V., Memoari, Dom i Svijet, Zagreb 2003.

Srpski ustavi od 1835. do 1990. godine sa ustavima Kraljevine SHS i Kraljevine Jugoslavije, opr. M. Radojević, Gramatik, Beograd 2004.

Stojadinović M., Ni rat ni pakt. Jugoslavija između dva rata, Rijeka 1970.

\section{PIŚMIENNICTWO}

Antić Č., Kratka istorija Srbije 1804-2004, Stubovi Kulture, Belgrad 2005.

Armstrong H.F., The Royal Dictatorship in Yugoslavia, „Foreign Affairs” 1929, t. 7, nr 4.

Balkovec B., Izborno zakonodavstvo prve jugoslavenske države (1918-1941), „Časopis za Suvremenu Povijest" 2016, t. 48, nr 1.

Banac I., With Stalin Against Tito: Cominformist Splits in Yugoslav Communism, Cornell University Press, New York 1988.

Bellamy A.J., The Formation of Croatian National Identity. A Centuries Old Dream?, Manchester University Press, Manchester \& New York 2003, https://doi.org/10.7228/manchester/ 9780719065026.001 .0001$.

Bojković D., The Communist Party of Yugoslavia during the Autocratic Rule of King Aleksandar Karađorđević, „Tokovi Istorije” 2015, nr 3, https://doi.org/10.31212/tokovi.2015. 3.boj.65-87.

\footnotetext{
59 Х. Зундхаусен, Историја Србије од 19. до 21. века, Београд 2009, s. 292.
} 
Bonarek J., Czekalski T., Sprawski S., Turlej S., Historia Grecji, Wydawnictwo Literackie, Kraków 2005.

Čalić M.-Ž., Istorije Jugoslavije u 20 veku, tł. R. Gašić, V. Babić, Clio, Beograd 2010.

Čirić D., Gradski nomad - beogradski zapisi fotoreportera Aleksandra Ace Simicia, Muzej Grada Beograda, Beograd 2011.

Čulinović F., Državnopravni razvitak Jugoslavije, Pravni Fakultet u Zagrebu, Zagreb 1963.

Daskalov R., Development in the Balkan Periphery Prior to World War II. Some Reflections, „Südost-Forschungen” 1998, nr 57.

Despalatović Elinor, The Roots of the War in Croatia, [w:] Neighbours at War. Anthropological Perspectives on Yugoslav Ethnicity, Culture and History, red. J.M. Halpern, Pennsylvania State University Press, Pennsylvania 2000.

Djokić D., Elusive Compromise. A History of Interwar Yugoslavia, Columbia University Press, New York 2007.

Dymarski M., Nikola Pašić, (1845-1926) - serbski radykalny konserwatysta, „Studia Środkowoeuropejskie i Bałkanistyczne” 2016, nr XXIV, https://doi.org/10.4467/2543733xssb. 16.004.6246.

Fira A., Vidovdanski ustav, Srpska Akademija Nauk i Umetnosti, Beograd 2011.

Isić M., Seljaštvo u Srbiji 1918-1941, cz. 3, Politički život na selu, Institut za Noviju Istoriju Srbije, Beograd 2015.

Lampe J., Balkans into Southeastern Europe, 1914-2014. A Century of War and Transition, Palgrave Macmillan, Hampshire 2014, https://doi.org/10.1007/978-1-137-05777-8.

Miškulin I., „Pribićevićevi ljudi” - Samostalna demokratska stranka u Slavoniji i Srijemu 1924-1929, „Scrinia Slavonica” 2015, nr 15.

Mizerski E., Jugosłowiański system przedstawicielski 1918-1990 (w zarysie), Wydawnictwo Adam Marszałek, Toruń 1999.

Newman J.P., Post-Imperial and Post-war Violence In the South Slav Lands, 1917-1923, „Contemporary European History” 2010, t. 19, nr 3, https://doi.org/10.1017/s09607773 10000159.

Nielsen Ch., Making Yugoslavs: Identity in King Aleksandar's Yugoslavia, Toronto University Press, Toronto 2014.

Pavlowitch S.K., Serbia: The History Behind the Name, C. Hurst \& Co. Publishers, London 2002.

Pešić M.D., Mladenović B.B., Funkcjonisanje parlamentarnog sistema u Kraljevini Srbiji od 1889. do 1892. godine, „Istorijski Czasopis” 2016, nr 65.

Pirjevec J., Jugoslavija. Nastanek, razvoj ter razpad Karadjordjevićeve in Titove Jugoslavije, Založba Lipa, Koper 1995.

Popović-Obradović O., The Parliamentary System in Serbia 1903-1914, Helsinki Committee for Human Rights in Serbia, Belgrade 2013.

Ramet S., The Three Yugoslavias. State-building and Legitimation, 1918-2005, Indiana University Press, Washington 2006.

Roszkowski S., S.H.S. Szkice z Jugostawji, E. Wende, Warszawa 1921.

Seton-Watson R.W., The Background of the Jugoslav Dictatorship, „The Slavonic and East European Review" 1931, t. 10, nr 29.

Seton-Watson R.W., Jugoslavia and Croatia, „Journal of the Royal Institute of International Affairs" 1929, t. 8, nr 2.

Stanković Đ., Nikola Pašić i jugoslovensko pitanje, t. 2, Beogradski izdavačko-grafički zavod, Beograd 1985.

Starzyński S., Współczesny ustrój prawno-polityczny Polski i innych państw słowiańskich, Wydawnictwo Sejmowe, Warszawa 2010. 
Stys Hubert, Zarys historii politycznej Komunistycznej Partii Jugosławii (lata 1919-1929), „Historia i Polityka” 2008, nr VII.

Šuklje F., Centralism and Autonomy in Jugoslavia, „The Slavonic Review” 1923, t. 2, nr 5.

Sundhaussen H., Istorija Srbije od 19. do 21. veka, Clio, Beograd 2009.

Szulc W., Przemiany gospodarcze i społeczne w Jugosławii w okresie międzywojennym 1918-1941, Wydawnictwo Naukowe UAM, Poznań 1980.

Zacharias M.J., Polityka KPJ i kwestia narodowościowa w Jugosławii w latach 1919-1943, „Studia z Dziejów Rosji i Europy Środkowo-Wschodniej” 2004, t. XXXIX. 